\section{Protective Effect of Ozone in Mice against Whole-body $\mathbf{X}$-irradiation}

Most of the radiobiological protection substances reported in the past are effective when they are administered during, or just before, irradiation, or when given in seriously toxic doses. Therefore, they are of little value for practical purposes except such a case as will be expected preliminarily in medical irradiation. The ideal radiobiological protection substance should give longer tolerance to radiation as in the case of an ideal agent against infectious disease-vaceine. Betz ${ }^{1}$ and Cronkite et $a .^{2}$ have reported the change of the effects of wholebody pre-X-irradiation resulted in a reduced mortality rate in mice. But this previous irradiation should be avoidod in consideration of cumulative genetic effect of radiation. We have adopted the inhalation of ozone of relatively low concentration as a previously administrative agent for radiation protection. Ozone is well known as radiomimetic ${ }^{3}$, but neither a leucopenia nor the existence of ozone was determined in the blood of the mice exposed in a relatively low concentration of ozone.

Adult male albino mice ( $N A .2$ strain) were used $(18-20 \mathrm{~g})$. The animals were placed in a large exposure chamber of $1.5 \mathrm{ft}^{3}$ capacity. The ozone was genorated from silica-gel dried air in a commorcial ozonizer and driven into a mixing chamber where the ozone concen tration was controlled by introducing the metered fresh air. This air-controlled ozone was introduced into the exposure chamber and exhausted through absorbers. $\mathrm{X}$-irradiation was carried out using $230 \mathrm{kV}, 20$ m.amp, copper filter $0.5 \mathrm{~mm}$ and aluminium filter $0.5 \mathrm{~mm}$, focal distance $80 \mathrm{~cm}$, field $650 \mathrm{~cm}^{2}, \mathrm{r} . / \mathrm{min}$ measured in air $50 \cdot 6$. Uniformity of dosage was ensured by rotating the irradiation cage during the irradiation. Some of the results obtained in this experiment are shown in Table 1. The mice exposed only once in 1 p.p.m. ozone for $1 \mathrm{~h}$, a concentration which caused no apparent injury to them, were then X-irradiated to $800 \mathrm{r}$. after ten days. 60 per cent of such treated animals survived whereas all the untreated animals died within 30 days. The mice previously exposed in 2 p.p.m. of ozone for only 0.5 or $0.25 \mathrm{~h}$ were then irradiated to $550 \mathrm{r}$. $\left(L D_{60 / 30}\right.$ days $)$ after $24 \mathrm{~h}$. They all survived.

Table 1. Tolerance to Whole-Body X-irradration BY Prevrous INHALATION OF OZONE IN MICE

\begin{tabular}{|c|c|c|c|c|c|}
\hline $\begin{array}{l}\text { Animal } \\
\text { group }\end{array}$ & $\begin{array}{r}\text { Pre-ex } \\
0 z \\
\text { Concen- } \\
\text { tration } \\
\text { (p.p.m.) }\end{array}$ & $\begin{array}{l}\text { osure to } \\
\text { one } \\
\text { Exposure } \\
\text { time } \\
\text { (h) }\end{array}$ & $\begin{array}{c}\text { Interval between } \\
\text { pre-exposure } \\
\text { to ozone and } \\
\text { X-irradiation } \\
\text { (day) }\end{array}$ & $\begin{array}{l}\text { Radia- } \\
\text { tion } \\
\text { dose } \\
(\mathrm{r} .)\end{array}$ & $\begin{array}{l}\text { Mortality } \\
\text { Dead No./ } \\
\text { Exposed No. }\end{array}$ \\
\hline $\begin{array}{l}\text { Pre-exposed } \\
\text { Control }\end{array}$ & 2 & $1 / 4$ & 1 & $\begin{array}{l}550 \\
550\end{array}$ & $\begin{array}{r}0 / 20 \\
12 / 20\end{array}$ \\
\hline $\begin{array}{l}\text { Pre-exposed } \\
\text { Control }\end{array}$ & 2 & $1 / 2$ & $\mathbf{1}$ & $\begin{array}{l}550 \\
550\end{array}$ & \\
\hline $\begin{array}{l}\text { Pre-exposed } \\
\text { Control }\end{array}$ & 1 & 1 & 1 & $\begin{array}{l}550 \\
550\end{array}$ & $\begin{array}{r}0 / 20 \\
12 / 20\end{array}$ \\
\hline $\begin{array}{l}\text { Pre-exposed } \\
\text { Control }\end{array}$ & 1 & 1 & 10 & $\begin{array}{l}800 \\
800\end{array}$ & $\begin{array}{r}8 / 20 \\
20 / 20\end{array}$ \\
\hline
\end{tabular}

Strictly speaking, the nitrogen dioxide was generated under the same conditions as that of ozone already mentioned, but its concentration was below 0.05 p.p.m. whereas that of ozone was 1 p.p.m. Therefore, nitrogen dioxide seemed to have no effect on the results obtained even at reasonably high concentrations.

Tolerance to radiation by previous inhalation of ozone lasted 30 days or more. If a product of concentration of ozone to exposure time were constant in a range of certain value, much lower concentrations of ozone than 1 p.p.m. might be usod without reducing the capacity of tolerance to radiation. Several considerations and cxperiments for species specificity and physiological state are necessary with reference to the cross-tolerance development ${ }^{4}$ and the stress theory; but the rapid dovelopment of tolerance to radiation and its long duration will be expected by using our method of previous inhalation of ozone which has apparently non-toxic concentration.

\section{KEIKO HATTORI \\ NORIO Kato \\ Masahtro Kinoshita \\ SyosakU Kinoshita \\ Tsuroshi Sunada}

Division of Sanitary Engineering,

Radiation Centre of Osaka Prefecture, Sakai, Osaka, Japan.

${ }^{1}$ Betz, H., C.R. Soc. Biol., 144, 1439 (1950).

${ }^{2}$ Cronkite, E. P., et al., Proc. Soc. Exp. Biol. Med., 73, 184 (1950).

${ }^{3}$ Brinkman, R., and Lamberts, H. B., Nature, 181, 1202 (1958).

${ }^{4}$ Stokinger, H. E., and Scheel, L. D., Amer. Med. Assoc. Arch. Environmental Health, 4, 327 (1962).

\section{Contamination of Leaves by Radioactive Fall-out}

ATtempts havo been made to evaluate the factors relating to the rate of fall-out and the cumulative deposition by means of multiple regression techniques using data for millk $^{1}$ and total diet ${ }^{2}$ obtained over a long period of observations. Field and laboratory experiments also provided results.

Leafy vegetables have been proved to be the main passage route of short-lived radionuclides in Japan ${ }^{3}$ in contrast to liquid milk in other countries. Hence, emphasis should be also placed on leafy vegetables with regard to the entry of long-lived radionuclides into man by direct contamination. Foliar contamination with strontium-90 and cesium-137 could be well interpreted on the basis of observations obtained for short-lived radionuclides such as iodine-131 and zirconium-niobium-95, in which case absorption from soil is negligible.

Measurements were made on the concentrations of iodine-131 and zirconium-niobium-95 in daily samples of dust and in spinach twice a week obtained from the market during the period of September 12-November 14, 1962.

The averages for the whole period showed 0.48 and 0.54 $\mu \mu c$. of iodine-13I and 0.75 and $2 \cdot 2 \mu \mu \mathrm{c}$. of zirconiumniobium-95 in $1 \mathrm{~m}^{3}$ air and $1 \mathrm{~g}$ fresh spinach, respectively. The difference in the ratio of concentrations in spinach to air between these radionuclides could be ascribed to the accumulation and decay of the radionuclides in spinach. In order to ostimate from the observed data, an exponential model analogous to the calculation of body-burden with radioisotopes has boon assumed:

$$
Q=\frac{f q}{\lambda}\left(1-e^{-\lambda t}\right)
$$

in which $Q=$ foliar contamination ( $\mu \mu c . / g$ fresh vegetable); $q=$ concentration in air $\left(\mu \mu \mathrm{c} . / \mathrm{m}^{3}\right) ; f=$ fraction of that in air which is retained on the vegetable; $\lambda=$ decay coefficient of a radionuclide $=0 \cdot 693 / T$, where $T$ is physical halflife (day); $t=$ mean exposure time of the vegetable to air (day).

Taking $Q$ and $q$ as observed values, $T$ as $8 \cdot 1$ and 65 days for iodine-131 and zirconium-niobium-95, respectively, $f$ would be given as a function of $t$ (Fig. 1). If, for the first approximation, $f$ were considered to be common to these radionuclides, the mean exposure time of spinach to contaminated air would be 35 days and the value of 0.10 would be obtained for $f$.

In the case of a radionuclide of longer half-life, such as cusium-137 or strontium-90, the foliar contamination. would be given as:

$$
Q=f q t
$$

Observed values of the concentration of exsium-137 in air for the period of November 1961-June 1962 are shown in Table 1. Hence, the foliar contamination with 